\title{
Phylogenetic or environmental control on the elemental and organo-chemical composition of Sphagnum mosses?
}

\author{
Juul Limpens $(\mathbb{D}) \cdot$ Elisabet Bohlin • Mats B. Nilsson
}

Received: 10 October 2016 / Accepted: 28 March 2017 /Published online: 10 April 2017

(C) The Author(s) 2017. This article is published with open access at Springerlink.com

\begin{abstract}
Background and aims Plant litter chemistry is a key driver of decomposition in peatlands. This study explored the relative contributions of phylogeny and environment to litter chemistry of peat mosses (Sphagnum), the key peat-forming plants on earth.

Methods Fifteen Sphagnum species, representing three taxonomic sections ACUTIFOLIA, CUSPIDATA and SPHAGNUM, were sampled across a wide range of hydro-geochemical conditions. For all species we characterised chemical composition within (i) inorganic elements, (ii) carbohydrate polymers (iii) noncarbohydrates.

Results The variation in carbohydrates was mostly explained by taxonomic section, suggesting phylogenetic conservation of carbohydrate composition. ACUTIFOLIA species invested relatively more in
\end{abstract}

Responsible Editor: Philip John White.

Electronic supplementary material The online version of this article (doi:10.1007/s11104-017-3239-4) contains supplementary material, which is available to authorized users.

\section{J. Limpens $(\bowtie)$}

Plant Ecology and Nature Conservation group, Wageningen University, Droevendaalsesteeg 3a, 6708 PB, Wageningen, the Netherlands

e-mail: Juul.Limpens@WUR.nl

E. Bohlin • M. B. Nilsson $(\bowtie)$

Soil Science, Biogeochemistry Department of Forest Ecology and Management, Swedish University of Agricultural Sciences,

Skogsmarksgränd 1, S-901 83 Umeå, Sweden

e-mail: Mats.B.Nilsson@SLU.se pectins, whereas CUSPIDATA and SPHAGNUM species invested more in hemicellulose. The composition of non-carbohydrates was mainly influenced by environment, except for some constituents for which the variation was more correlated to phylogeny. Finally, the variation in inorganic element concentrations mostly reflected hydro-geochemical conditions within and between peatlands.

Conclusions The separation into an environmentally independent, phylogenetically conserved group of compounds (structural carbohydrates) and an environmentally dependent, variable group of compounds (inorganic elements, non-carbohydrates) has important implications both for understanding patterns in and for upscaling of spatially variable ecosystem processes associated with peat decomposition such as carbon sequestration, nutrient cycling and greenhouse gas emissions.

Keywords Environment - Litter chemistry · Mires · Peatlands · Phylogenetic control $\cdot$ Chemical traits . Sphagnum

\section{Introduction}

Production and decomposition of organic matter and the net return of carbon (C) to the atmosphere largely determine the strength of the soil-feedback to global warming. Organic matter decomposition is central to the development and functioning of the plant-soil system, controlling transfer rates of energy and carbon to 
the microbial community, the speed of nutrient cycling and potential nutrient losses (Bradford et al. 2002; Wardle et al. 2004). Two of the key controls on decomposition and mineralisation are the elemental stoichiometry and organo-chemical composition of the plant litter entering the soil, particularly in organic soil layers and soils (Minderman 1968; Melillo et al. 1982; Ågren and Bosatta 1996; Aerts 1997). But what, in turn drives the chemical litter composition? Is it an emergent feature of the environment the plants grow in, or is it an evolutionary trait that can be tracked through the plant species' phylogeny? Separating the environmentally-variable and environmentally stable chemical components of the litter is essential to upscale and predict spatially variable processes controlled by litter quality, such as nutrient cycling, carbon sequestration, and greenhouse gas emissions.

We focussed our study on northern hemisphere peatlands, one of the world's biggest soil carbon reserves. These ecosystems store approximately $400 \mathrm{Pg}$ of $\mathrm{C}$ as peat, (Loisel et al. 2014), amounting to about half of the $\mathrm{C}$ currently in the atmosphere as $\mathrm{CO}_{2}$ (IPCC 2013). Besides being a sink for atmospheric $\mathrm{CO}_{2}$, peatlands are also a major source of methane $\left(\mathrm{CH}_{4}\right)$, making them crucial players in the global $\mathrm{C}$ cycle (Olefeldt et al. 2013). Most of the high latitude peatlands are dominated by peat forming mosses from the genus Sphagnum. Here, up to 90 vol.\% of the peat consists of Sphagnum litter, that may retain its macro-structure for decades after the plant has died (Turetsky 2003; Loisel et al. 2014). The slow litter decomposition in peatlands is generally attributed to the additive effects of environmental factors, such as acidic and nutrient-poor soil conditions above and anoxic conditions below the water table, and the chemical composition of the litter, particularly Sphagnum (Clymo 1965). In turn the acidic, nutrient poor and wet environment is a function of the chemical and structural properties of Sphagnum litter and peat (Clymo 1963; Van Breemen 1995), illustrating its role as ecosystem engineer. The direction and degree in which the physical and chemical properties at the peat surface are affected by Sphagnum strongly depends on Sphagnum species (Hayward and Clymo 1982), suggesting clustering of species and/or traits into strategies (Bengtsson et al. 2016).

The most commonly used distinction of "clusters" within the genus Sphagnum is that based on the microtopographical position of the species above the water table, separating species occupying dry hummocks from those occupying moist lawns and wet hollows. The micro-topography itself is an emergent feature of the species themselves and is not related to the underlying mineral soil (Belyea and Baird 2006). Dry hummock species show a conservative resource strategy (cf. Coley et al. 1985; Grime et al. 1990) maximising nutrient and water retention by combining highly recalcitrant litter (Turetsky et al. 2008), high cation exchange capacity (Clymo 1963; Spearing 1972), and dense canopy structure (Hayward and Clymo 1982; Laing et al. 2014) at the cost of low maximum growth rates (Hájek 2009; Laing et al. 2014). Wet hollow species show a contrasting strategy, maximising growth rate instead by lowering litter recalcitrance, cat-ion exchange capacity and water retention. Lawn species generally take up an intermediate position. The distinct differences in growth strategies between hummock and hollow species coincide with differences in resource allocation to structural vs. metabolic carbohydrates (Turetsky et al. 2008), suggesting slow growing hummock species invest in poorly degradable carbohydrates, whereas faster-growing hollow species invest in easily degradable carbohydrates. The latter would indicate a causal relationships between species growth strategy and litter chemistry. To what extent this growth-decay trade-off is phylogenetically determined, or a consequence of the environment remains unresolved, however. The main taxonomic groups (sections) within the genus Sphagnum correlate partly with position along the hummock-hollow gradient (Vitt and Slack 1984; Gignac 1992; Bragazza 1997), and both taxonomic group and position along the hummock-hollow gradient are closely correlated to phylogenetic relatedness (Shaw 2000; Johnson et al. 2014). Consequently, it seems reasonable to assume that at least part of the carbon-based litter chemistry is related to phylogeny. Despite the latter, there is also evidence pointing towards an important environmental contribution to litter chemistry, as for example illustrated by the large intraspecific variation in innate decay rates, and thus presumably litter chemistry, reported in Bengtsson et al. (2016), the high correlation between major plant nutrients and the position of the same species along a nitrogen deposition gradient (Bragazza et al. 2005) and the correlation between inorganic element concentrations and acidity-alkalinity related gradients (Wheeler and Proctor 2000). The close interrelationship between environment, phylogeny and ecosystem functioning make peatlands in general and the genus Sphagnum in particular an ideal model ecosystems to separate effects of environment and phylogeny on litter chemistry. 
In this study we set out to explore the relative contributions of environment (peatland type, ecohydrological position within peatland) and phylogeny (taxonomic sections within the genus Sphagnum) in explaining the chemical composition of 15 Sphagnum species. In our analysis we distinguished between three chemistry types: (i) inorganic elements, (ii) carbohydrate polymers (polysacharides) and (iii) noncarbohydrates (aromatic and aliphatic constituents). We expected that the variation in inorganic element content between Sphagnum samples would mainly reflect growing conditions, i.e. the environment, whereas the variation in carbohydrate and non-carbohydrate contents would be explained mostly by phylogeny.

\section{Materials and methods}

Sites and sampling

Our study area was the province of Västerbotten, northern Sweden. The climate of the area is cold temperate humid (Dfc, Köppen classification system, McKnight and Darrel 2000) with the mean annual temperature ranging between $+1{ }^{\circ} \mathrm{C}$ and $+3{ }^{\circ} \mathrm{C}$ (reference period 1961-1990). The mean (1961-1990) January temperature ranges from $-9{ }^{\circ} \mathrm{C}$ at the coast to $-11^{\circ} \mathrm{C}$ at the more inland sites. The mean July temperature is $+15^{\circ} \mathrm{C}$ in the entire region. Mean (1961-1990) annual precipitation is 600 at the coast and $700 \mathrm{~mm}$ further inland, with a January mean of $50 \mathrm{~mm}$ and a July mean between 50 and $70 \mathrm{~mm}$ (Alexandersson et al. 1991). Of the annual precipitation $\sim 50 \%$ is lost through evapotranspiration (Laudon et al. 2013).

Within Västerbotten we selected seven peatlands that cover much of the environmental variation that can be found in Scandinavian peatlands and represent differences in minerotrophy as well as nutrient richness (Table 1). Selection of peatlands was based on the mire-type classification of Eurola et al. (1984). This classification is based on a combination of physical characteristics and vegetation composition and correlates well with longer-term contrasts in water chemistry (Eurola et al. 1984). Six of the peatlands selected are located in the coastal area, below the highest shoreline (Renberg and Segerström 1981), one peatland (Björnmyran) is situated more inland (Table 1).

From the seven peatlands selected we collected material from 15 Sphagnum species (Table 2) of three common and wide-spread taxonomic sections (CUSPIDATA, SPHAGNUM, ACUTIFOLIA). Each Sphagnum species was collected in one to six peatlands in the second half of August in 1993.

The Sphagnum species were chosen from contrasting micro-topographical locations (referred to as microsites), differing in average water table level (Table 2). Sampled microsites comprised hollows with the average growing season water table close to the moss surface $(0-10 \mathrm{~cm}$ below surface), moist lawns $(10-20 \mathrm{~cm}$ below surface) and hummocks ( $>20-25 \mathrm{~cm}$ below surface). In addition, species were chosen both from peatland centres and peatland margins. For each species, on each peatland, a sampling area with a radius of about $5 \mathrm{~m}$ was defined. In each sampling area eight subsamples were collected and checked microscopically before merging them into one sample for chemical analyses. On each sampling area the occurrences of accompanying plant species were recorded in eight sub-plots of $20 \times 20 \mathrm{~cm}$ (Table S1) Although the accompanying species differed between peatland and microsite, the variation was such that none of the species or sections had $100 \%$ identical accompanying species.

The samples were kept in cold storage $\left(+4{ }^{\circ} \mathrm{C}\right)$ until preparation. The mosses were cleaned from litter, vascular plant roots and other plant material. After this each individual was cut with a pair of scissors at the transition between brown, senesced tissue and pigmented, photosynthetic active tissue. Only the pigmented photosynthetically active part $(1 \sim 10 \mathrm{~cm}$, short for hummock species, long for hollow species), comprising both capitulum, stem and branches, was used for the chemical analyses. The plant material was dried at $40{ }^{\circ} \mathrm{C}$ for $48 \mathrm{~h}$ until constant weight and stored until analysis. Time between sampling, preparation and drying was maximally three days. Prior to the chemical analyses, that were made within two years after sampling, the dried Sphagnum plant material was milled and sieved (0.25 mm mesh size).

\section{Chemical analysis}

All our analyses are a result of chemical digestion or pyrolysis of the entire plant tissue. Consequently, our chemical characterisation mostly represents the structural rather than the metabolic components of the plant material. 
Table 1 Location and name of the seven peatlands sampled within this study

\begin{tabular}{llllll}
\hline Peatland & Code & Coordinates* & Elevation & Peatland type & \\
\cline { 5 - 5 } & & WGS84* & m.a.s.l. & general & specific \\
\hline Björnmyran & $\mathrm{B}$ & $64^{\circ} 19^{\prime} \mathrm{N} 18^{\circ} 08^{\prime} \mathrm{E}$ & 398 & Medium rich fen & Mesotrophic tall sedge fen \\
Kroktjärnmyran & $\mathrm{K}$ & $64^{\circ} 21^{\prime} \mathrm{N} 20^{\circ} 14^{\prime} \mathrm{E}$ & 237 & Poor fen & Sphagnum fuscum true short sedge fen \\
Sjulsmyran & $\mathrm{J}$ & $64^{\circ} 01^{\prime} \mathrm{N} 20^{\circ} 38^{\prime} \mathrm{E}$ & 70 & Poor fen & Poor Sphagnum papillosum fen with small flarks \\
Stor-Åmyran & $\mathrm{S}$ & $63^{\circ} 44^{\prime} \mathrm{N} 20^{\circ} 05^{\prime} \mathrm{E}$ & 38 & Bog & Calluna Sphagnum fuscum bog \\
Stor-Vidmyran & $\mathrm{I}$ & $64^{\circ} 24^{\prime} \mathrm{N} 20^{\circ} 10^{\prime} \mathrm{E}$ & 276 & Fen & Pine fen with flarks \\
Torsmyran & $\mathrm{T}$ & $63^{\circ} 35^{\prime} \mathrm{N} 19^{\circ} 36^{\prime} \mathrm{E}$ & 49 & Bog & Calluna Sphagnum fuscum bog \\
Våtömyran & $\mathrm{V}$ & $63^{\circ} 40^{\prime} \mathrm{N} 20^{\circ} 11^{\prime} \mathrm{E}$ & 12 & Poor fen & Poor Sphagnum papillosum fen
\end{tabular}

Code used as site abbreviation in Table 2. * World Geodetic System of 1984. Peatland types cf. Eurola et al. 1984

Elements

We distinguished 10 elements in total: sodium $(\mathrm{Na})$, potassium $(\mathrm{K})$, magnesium $(\mathrm{Mg})$, calcium $(\mathrm{Ca})$, manganese $(\mathrm{Mn})$, aluminum $(\mathrm{Al})$, iron $(\mathrm{Fe})$, phosphorus $(\mathrm{P})$, nitrogen $(\mathrm{N})$ and sulphur $(\mathrm{S})$. All elements except $\mathrm{N}$ were determined with ICP-AES (Perkin Elmer, Plasma 2000) after digestion of 195-205 mg (DW) plant material in a mix of $\mathrm{HNO}_{3}(65 \%)$ and $\mathrm{HClO}_{4}(70 \%)$ at $110^{\circ}$ - $130^{\circ} \mathrm{C}$ for $3 \mathrm{~h}$. Detection limit was determined as 3SD for repetitions of reference mixture containing $5 \mathrm{ppm}$ of each sample. Total nitrogen $(\mathrm{N})$ was determined using elemental analyser (Perkin Elmer, CHN 2400).

\section{Carbohydrate polymers}

Carbohydrates were assessed as neutral sugar constituents (alditol acetates) derived from polysaccharides

Table 2 Overview of 15 Sphagnum species sampled with details on taxonomic section (ACUTIFOLIA, CUSPIDATA, SPHAGNUM), characteristic microsite (wet hollow, moist lawn and dry hummock) and peatlands where the species were collected

\begin{tabular}{|c|c|c|c|c|c|c|c|c|c|c|}
\hline Sphagnum species & Taxonomic section & Microsite & $\mathrm{B}$ & K & $\mathrm{J}$ & $\mathrm{S}$ & I & $\mathrm{T}$ & V & Total \\
\hline S. jensenii & CUSPIDATA & hollow & BJE & & & & & & & 1 \\
\hline S. lindbergii & CUSPIDATA & hollow & BLI & KLI & JLI & SLI & & TLI & VLI & 6 \\
\hline S. majus & CUSPIDATA & hollow & & KMJ & JMJ & SMJ & & TMJ & VMJ & 5 \\
\hline S. pulchrum & CUSPIDATA & hollow & & & JPU & & & TPU: & VPU & 3 \\
\hline S. tenellum & CUSPIDATA & hollow & & & & STE & ITE & TTE & VTE & 4 \\
\hline S. balticum & CUSPIDATA & lawn & & & & SBA & & & & 1 \\
\hline S. fallax & CUSPIDATA & lawn & & KFA & JFA & SFA & & TFA & VFA & 5 \\
\hline S. magellanicum & SPHAGNUM & lawn & BMA & KMA & JMA & SMA & & & VMA & 5 \\
\hline S. papillosum & SPHAGNUM & lawn & BPA & KPA & JPA & SPA & & $\operatorname{TPA}^{a}$ & VPA & 6 \\
\hline S. russowii & ACUTIFOLIA & lawn & & KRU & & SRU & & TRU & VRU & 4 \\
\hline S. girgensohnii* & ACUTIFOLIA & lawn & & KGI* & $\mathrm{JGI}^{*}$ & SGI* $^{*}$ & & TGI* & & 4 \\
\hline S. subfulvum & ACUTIFOLIA & lawn & $\mathrm{BSU}$ & & & & & & & 1 \\
\hline S. capillifolium & ACUTIFOLIA & hummock & & $\mathrm{KCA}$ & & $\mathrm{SCA}$ & & TCA & $\mathrm{VCA}$ & 4 \\
\hline S. fuscum & ACUTIFOLIA & hummock & $\mathrm{BFU}$ & $\mathrm{KFU}$ & JFU & SFU & & TFU & $\mathrm{VFU}$ & 6 \\
\hline S. warnsdorfii & ACUTIFOLIA & hummock & BWA & & & & & & & 1 \\
\hline Total & & & 7 & 9 & 8 & 11 & 1 & 10 & 10 & 56 \\
\hline
\end{tabular}

Sample codes are used in Figs. 1, 2, 3 and 4 and are based on a combination of the first letter of the peatland (Table 1) and the first two letters of the species name

*- growing at peatland margins on shallow or no peat at all, i.e. not reflecting the nutrient conditions in the peatland centre

$a$ - growing in a transitional fen between the bog and the upland forest 
using sulphuric acid hydrolysis $\left(72 \% \mathrm{H}_{2} \mathrm{SO}_{4}, 30{ }^{\circ} \mathrm{C}\right.$, $1 \mathrm{~h}$; dilution to $2.5 \%$, autoclaved at $125^{\circ} \mathrm{C}, 1 \mathrm{~h}$ ) followed by derivatization and gas capillary chromatography (Theander and Westerlund 1986). Quantification was made using myo-inositol as internal standard. The hydrolysis yielded seven analysable carbohydrate monomers: the two pentoses (arabinose and xylose) and five hexoses (fucose, galactose, glucose, mannose and rhamnose).

Non-carbohydrates (aromatic and aliphatic compounds)

The dried and milled samples were suspended in $2 \mathrm{ml}$ ultrapure-water and $200 \mu \mathrm{l}$ ethanol and then treated for 15 min. in an ultrasonic bath. Pyrolysis was performed using a foil pulse pyrolyser; "Pyrola", Pyrol AB, Lund, Sweden (Tydén-Ericsson 1973); $3 \mu$ of the suspension (approximately $50 \mu \mathrm{g}$ sample) was placed in a cavity in a platinum foil. Pyrolysis conditions were as follows: chamber temperature $150{ }^{\circ} \mathrm{C}$, pyrolysis temperature $550{ }^{\circ} \mathrm{C}$, temperature rise time of $8 \mathrm{~ms}$ and total pyrolysis time $2 \mathrm{~s}$. Pyrolysis temperature was chosen to maximise the amount of substituted aromatic fragments (data not shown). The pyrolyser was connected to a HP (HewlettPackard) 5890 Gas Chromatograph equipped with a split injector utilising a split ratio of 1:15. The injector temperature was $250{ }^{\circ} \mathrm{C}$. A $15 \mathrm{~m}$ fused silica capillary column (coated with DB1301, id $0.26 \mathrm{~mm}$, film thickness $0.25 \mu \mathrm{m}$ ) was used for separation of pyrolysis products. The oven temperature was increased from $50{ }^{\circ} \mathrm{C}$ to $270{ }^{\circ} \mathrm{C}$ with a rate of $5{ }^{\circ} \mathrm{C}$ per min. Helium was used as carrier gas at a velocity of about $1.4 \mathrm{ml} /$ min. Eluting compounds were detected with a HP 5970 mass selective detector. The detector temperature was set to $180^{\circ} \mathrm{C}$. The electron impact ionisation energy was $70 \mathrm{eV}$ and the measured mass range $\mathrm{m} / \mathrm{z}=35-300$. Pyrolysis products were identified by comparison with the mass spectra present in the mass spectral data base belonging to the data system (HP 59973B Library software), or with mass spectra found in the literature (Boon et al. 1986; Van Smeerdijk and Boon 1987; Bracewell et al. 1980; Ralph and Hatfield 1991).

The original three-dimensional spectra (time, mass number and ion intensity) were transformed to two dimensions (time and total ion intensity). The baselines in these two-dimensional spectra (Total Ion Chromatograms, TICs or pyrolysis chromatograms, pyrograms) were adjusted. Based on the peaks in the pyrograms 34 regions were selected and integrated, yielding 34 fragments (Supporting information Table S2). The integration was made by summing the total ion intensity for each data point (scan) in the region. In order to eliminate most of the variations due to differences in amount of analysed sample, the integration sum for the 34 regions were normalised for each pyrogram. Of the 34 identified regions, 16 regions, known to represent carbohydrate polymers, were removed, focussing the data analysis of this study on the non-carbohydrates only.

\section{Data analysis}

We used a combination of multivariate and univariate statistics to explore the chemical composition of our Sphagnum samples, focussing on three functional chemistry types: (i) inorganic elements, (ii) carbohydrates (iii) non-carbohydrates. Chemical data were transformed to meet statistical assumptions prior to analyses, if applicable. In the multivariate analysis all variables were auto scaled to unit variance and centred in order to allow all constituents to contribute equally to the total variance.

We used Principal Component Analysis (PCA) to examine how much of the total variance within each of the three types of chemical constituents was explained by latent variables by optimising the covariance (PCcomponents) and how this reflected known environmental or phylogenetic clustering of the Sphagnum species. Four separate PCAs were run with 10 inorganic elements, seven carbohydrates and 18 noncarbohydrates respectively, and one PCA where we combined all chemical constituents in one analysis. To further reveal the contribution of environment and phylogeny to the covariance structures in chemistry, we treated environment and phylogeny as supplementary variables, i.e. they were fitted into the chemical ordination space but did not contribute to the PC ordination itself. To characterize environment we used the variables "peatland" (six groups), and "microsite" (three groups) and to characterize "phylogeny" we used the taxonomic sections within the genus Sphagnum (three groups).

To specifically quantify how much of the total variance within each of the three types of chemical constituents was explained by environment and phylogeny respectively, we performed a variation-partitioning procedure (based on RDA) for each chemistry type (elements, carbohydrate polymers, non-carbohydrates). To test if the degree of explained variation 
contributed by environment or phylogeny respectively differed between chemistry types we used a chi-square $\left(X^{2}\right)$ analysis.

Based on the PCAs we also selected 5 constituents, contributing the most to PC1 and PC2 within each chemistry type to test the strength of the main effects of peatland, microsite and taxonomic group, using univariate techniques (Generalized Lineair Model). The constituents chosen were the ones that i) correlated strongly with one of the four PCA ordination axes and ii) correlated least with the other chemical constituents. For the analyses microsite and taxonomic group were nested within collection site.

The choice for linear ordination methods (PCA, RDA) was based on the degree of turnover in chemical data, as inferred from the length (0.3 SD units, irrespective of chemical constituents) of the first Detrended Correspondence Analysis axis (Lepš and Šmilauer 2003). All multivariate analyses were performed with CANOCO Engine Version 5.0 (Braak and Šmilauer 2012). Univariate analyses were performed with IBM SPSS statistics 20 .

\section{Results}

On average Sphagnum dry mass consisted of 2\% ( \pm $0.07 \%$ se) inorganic elements, $46 \%$ ( $\pm 0.54 \%$ se) carbohydrates and $60 \%( \pm 0.48 \% \mathrm{se})$ non-carbohydrates. The non-carbohydrate fragments included some unidentified fragments, which might explain the $8 \%$ surplus of mass. Based on these three types of chemical constituents together, Sphagnum samples were clustered according to taxonomic section and peatland, illustrating the combined influences of environment and phylogeny on Sphagnum chemistry (Fig.1). Along the first ordination axis (PC1) samples from the ACUTIFOLIA section (negative scores) were separated from the CUSPIDATA and SPHAGNUM sections (neutral-positive scores). Along the second ordination axis (PC2), samples from the medium rich fen Björnmyran ( $\mathrm{B}^{* *}$, positive scores) were separated from samples from the bogs and poor fen Kroktjärnmyran ( $\mathrm{K}^{* *}$, negative scores). The ordination was primarily driven by the inorganic element contents and the non-carbohydrates, and less by carbohydrates, as indicated by the lower loading values for the carbohydrates (short arrows in the PCA graph, Fig. 1b).
Elements

Of the 10 inorganic elements analysed, nitrogen dominated with $42 \%( \pm 0.01 \%$ se) the total inorganic element content per Sphagnum sample. Based on content of all inorganic elements, Sphagnum samples from the same peatland were clustered more closely together than those from the same microsite or taxonomic section (Fig.2). The clearest separation along PC1 was between samples from the fen Björnmyran ( $\left.\mathrm{B}^{* *}\right)$ with positive scores and the two bogs Storåmyran $\left(\mathrm{S}^{* *}\right)$ and Torsmyran $\left(\mathrm{T}^{* *}\right)$ with negative scores. In line with the above, samples of S. girgensohnii, (*GI) a species from peatland margins, were clustered together with high scores on PC1. Along PC2, samples from the fen Björnmyran had highest positive scores closely followed by poor fen Sjulsmyran $\left(\mathrm{J}^{* *}\right)$. Most samples from the bogs Storåmyran and Torsmyran had scores close to zero and the lowest scores along PC2 were for samples from poor fen Kroktjärnmyran $\left(\mathrm{K}^{* *}\right)$. Repeating the ordination without $S$. girgensohnii maintained the positions of the peatland sites relative to each other.

The samples from fen Björnmyran were characterised by their high contents of elements $\mathrm{Fe}, \mathrm{Al}$, $\mathrm{Ca}, \mathrm{Mg}$ and $\mathrm{Mn}$ (Fig. 2, Table 3), whereas samples from the bogs Storåmyran and Torsmyran where mainly characterised by their low $\mathrm{Fe}$ content. Contents of $\mathrm{S}$ and plant nutrients $\mathrm{N}, \mathrm{P}$ and $\mathrm{K}$ were partly associated with specific peatland sites, sampling position within the peatland (centre vs margin) and microsite. Poor fen Kroktjärnmyran was characterised by high N, P, K and $\mathrm{S}$ contents. The peatland margin species $S$. girgensohnii reached the highest contents of N, P and K of all Sphagnum species. Within the peatland centre, species from lawn and hummocks were partly separated from those of hollows by their higher contents of N, P, and K and lower $\mathrm{Na}$ content.

\section{Carbohydrates}

Of the seven carbohydrate monomers analysed, glucose dominated with $56 \%( \pm 0.01 \%$ se) of the total carbohydrate content per Sphagnum sample. The PCA of the carbohydrate composition (Fig. 3) showed an entirely different pattern from that of element composition: samples of all three taxonomic sections were clearly separated by $\mathrm{PC} 1$ and $\mathrm{PC} 2$. The clearest distinction along PC1 was between samples from the ACUTIFOLIA section (negative scores) and the CUSPIDATA section 


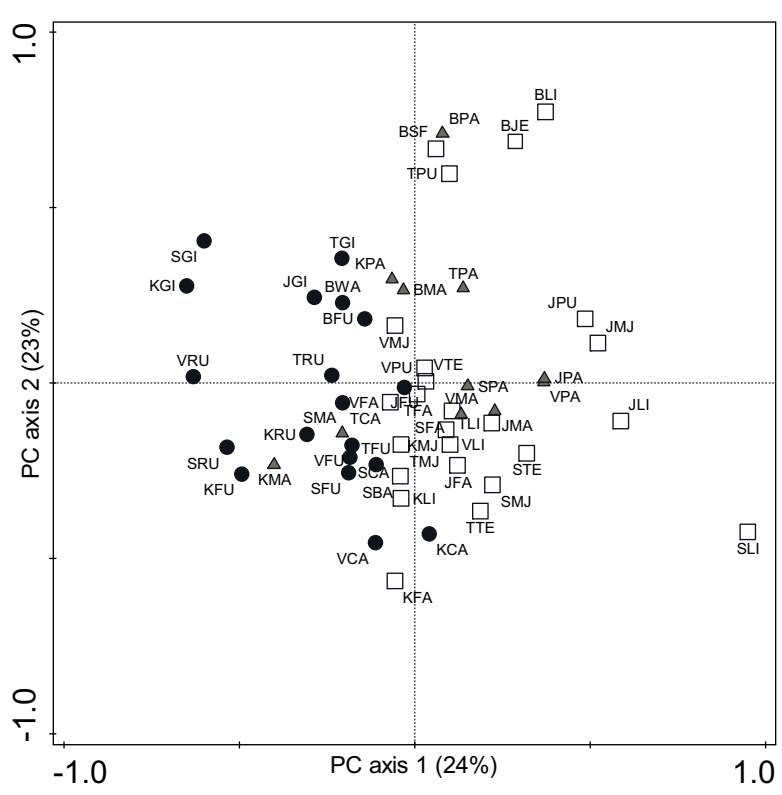

Fig. 1 PC ordination based on the contents of 10 inorganic elements, seven carbohydrate monomers and 18 noncarbohydrate fragments (F) from pyrolysis of 56 Sphagnum samples. Together, the four ordination axes of the PCA explained $69 \%$ of the total variation in elements among samples, with $47 \%$ being explained by the first two axes (PC1, PC2). Left panel: position of all Sphagnum samples in ordination space. Samples positioned closely to each other have similar chemical compositions. Open squares $=$ samples from the taxonomic CUSPIDATA section, solid grey triangles $=$ section SPHAGNUM and solid black circles $=$

(positive scores). The samples from the CUSPIDATA section were characterised by high contents of monomers such as fucose, galactose, glucose, arabinose and xylose, whereas ACUTIFOLIA samples had low contents of these same carbohydrates but were particularly high in rhamnose (Fig. 3, Table 4). Similar to the ACUTIFOLIA, samples from the SPHAGNUM section had lower scores on PC1. SPHAGNUM samples were characterised by high contents of mannose but also low content of rhamnose, separating the SPHAGNUM section from the other sections along PC2.

Non-carbohydrates

Of the 18 non-carbohydrate fragments analysed, fragment of unidentified origin F1 dominated with $47 \%$ ( \pm $0.002 \%$ se) the total non-carbohydrate content per Sphagnum sample. In comparison, fragments of known phenolic and aromatic origin (F16, F19, F25 and F28) made up $12 \%$. Based on non-carbohydrate composition the Sphagnum samples were separated according to

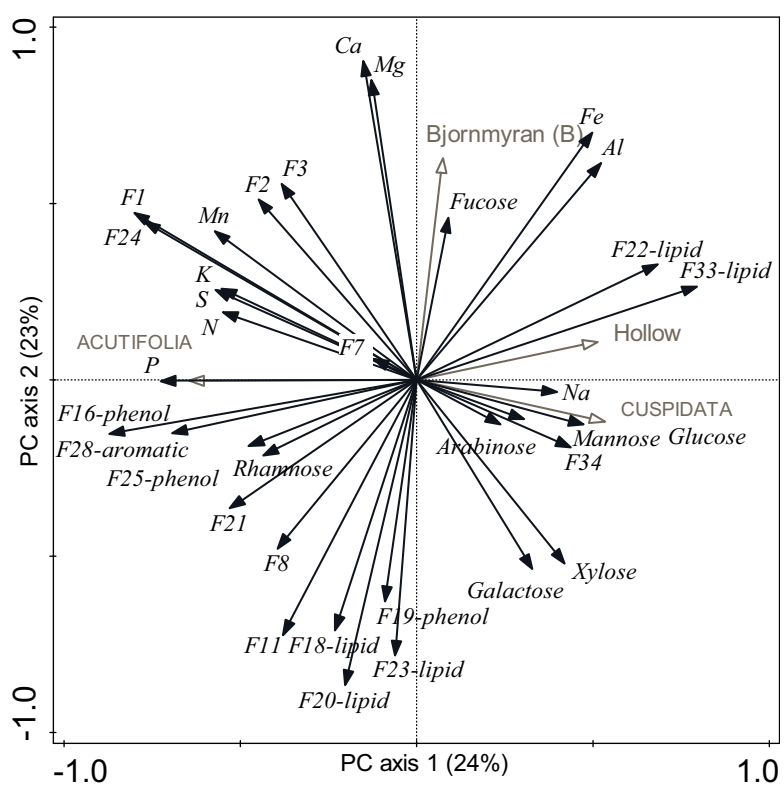

section ACUTIFOLIA. Sample codes consist of three letters: first letter indicates peatland identity whereas the second two letters are the first two of the scientific Sphagnum species name (see Table 2 for abbreviations). Right panel shows the correlation between the PC axes and the chemical contents (black arrows) and those supplementary variables (grey arrows) with a correlation coefficient $\leq-0.4$ or $\geq+0.4$ with PC1 and/or PC2. F6, F19 are characteristic of phenolic compounds, F20 of lipids, F2 and F33 are pyrolysis fragments of unknown origin (Table S2)

peatland and taxonomic section (Fig. 4). Separation of samples along PC1 was mainly related to taxonomic section, whereas separation along PC2 was more related to peatland and Sphagnum species within the ACUTIFOLIA section. ACUTIFOLIA samples were characterized by mostly negative PC1 scores (more aromatic fragments), however substantially overlapping with both CUSPIDATA and SPHAGNUM samples (Fig. 4, Table 5). PC1 was mainly characterised by high contents of lipid fragment F22 and fragment of unknown origin F33 (positive scores) and low contents of aromatic fragments (F16, F25, F28; negative scores). PC2 was characterized by positive correlation to lipid fragments (F11, F20, F23) and one phenolic fragment (F19) and negative correlation to two unknown fragments (F2, F3). The most obvious separation along PC2 was between samples of different species from the ACUTIFOLIA section. Here hummock species such as $S$. fuscum (*FU) and S. capillifolium (*CA) had high content of lipid fragments (F11, F20, F23) and one phenolic fragment (F19), i.e. high positive PC2 scores. 

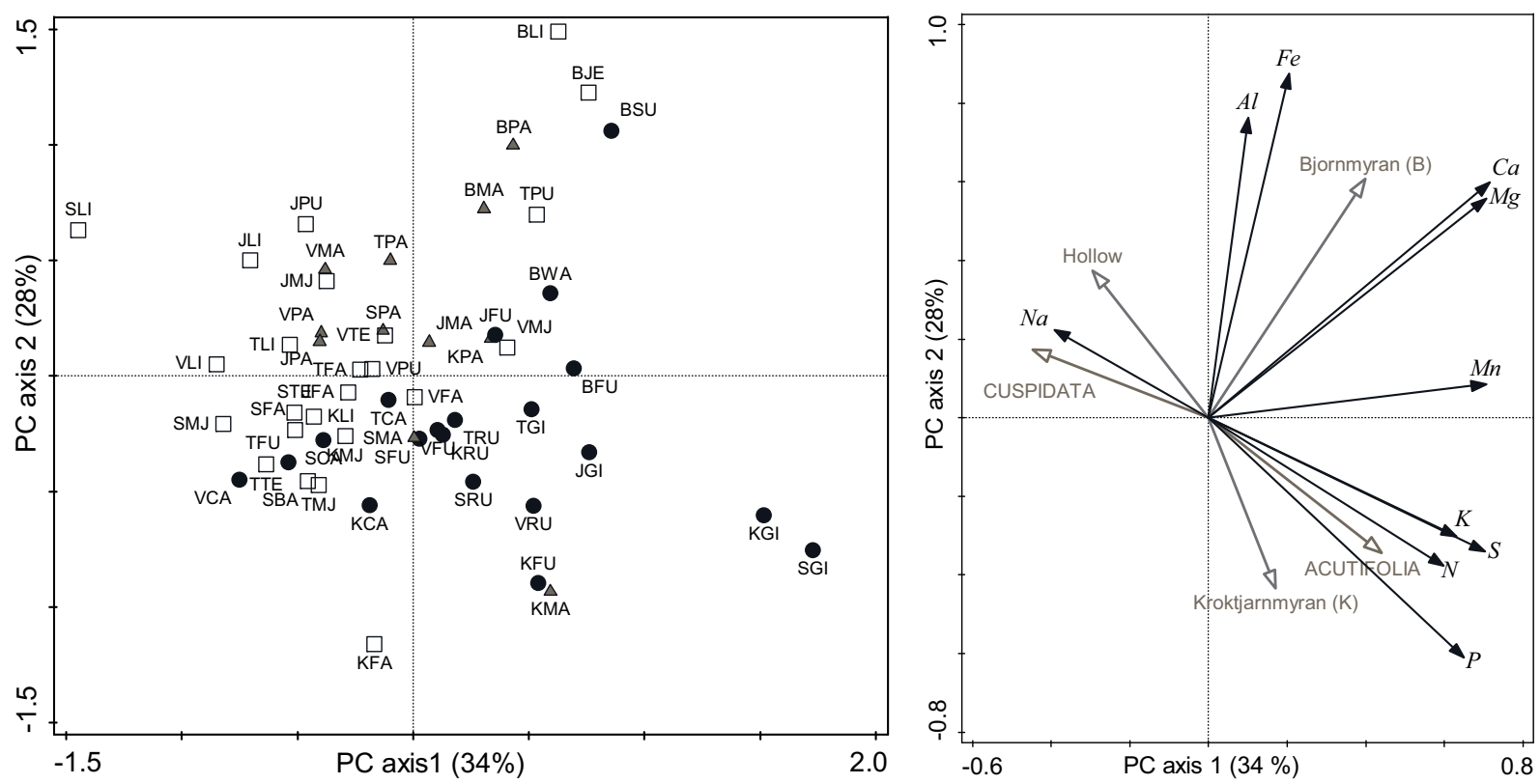

Fig. 2 PC ordination based on the contents of 10 inorganic elements of $55^{*}$ of the 56 Sphagnum samples. Together, the four ordination axes explained $84 \%$ of the total variation in elements among samples, with $62 \%$ being explained by the first two axes (PC1, PC2). Left panel: position of all Sphagnum samples in ordination space. Samples positioned closely to each other have similar chemical compositions. Open squares $=$ samples from the taxonomic CUSPIDATA section, solid grey triangles = section

Samples of peatland margin species $S$. girgensohnii (*GI) were low in the same fragments (negative scores) but had high contents of unknown fragments (F2, F3). Samples of the other peatland margin species $S$. russowii (*RU) scored around zero between S. fuscum and $S$. capillifolium and $S$. girgensohnii respectively along PC2. The second axis also to some extent separated samples from the poor fen Sjulsmyran $\left(\mathrm{S}^{* *}\right)$ from those of the medium rich fen Björnmyran $\left(\mathrm{B}^{* *}\right)$.

\section{Variance partitioning}

To further quantify the contributions of environment and phylogeny respectively, we performed a variationpartitioning procedure for inorganic elements, carbohydrates and non-carbohydrates respectively (Fig. 5, Table S3). Variation in inorganic element composition of Sphagnum was explained mainly by peatland (25\%), whereas microsite (7\%) and taxonomic section (10\%) were of considerable less importance (Fig. 5). In contrast to the element composition, only $5 \%$ of the variation in carbohydrate composition was explained by
SPHAGNUM and solid black circles $=$ section ACUTIFOLIA. For information about sampling codes see legend Fig. 1. Right panel shows the correlation between the PC axes and the element contents (black arrows) and those supplementary variables (grey arrows) with a correlation coefficient $\leq-0.4$ or $\geq+0.4$ with PC1 and/or PC2. * Sample ITE was omitted due to extremely high (> $2 * \mathrm{SE})$ Mn concentration

peatland site. Instead, taxonomic section explained $43 \%$ of the variation in carbohydrate composition between the Sphagnum samples of which $19 \%$ was shared with microsite, i.e. $24 \%$ was uniquely explained by taxonomic section. Microsite alone was not important in explaining the variation in carbohydrates $(3 \%)$. For the non-carbohydrates none of the variables could be identified as the main driver, although the contribution of environment seemed stronger than that of phylogeny: peatland and microsite explained $16 \%$ and $12 \%$ respectively, whereas taxonomic section explained $8 \%$, with half of the variation shared between microsite and taxonomic section.

\section{Discussion}

\section{Environment vs phylogeny}

We show a large variation in both elemental and organochemical composition among the 15 Sphagnum species sampled. We also show that the elemental and non- 
Table 3 Sample sizes (n), untransformed mean contents (\% dw) and standard errors (se) of 5 inorganic elements aggregated per taxonomic section, microsite and peatland. Only those elements with a strong correlation with one of the four PCA ordination axes
(Fig. 2) and low correlation with other elemental constituents were shown. Taken together the inorganic elements shown represent between $11 \%$ and $54 \%$ of the total inorganic element content per Sphagnum sample

\begin{tabular}{|c|c|c|c|c|c|c|c|c|c|c|c|}
\hline & $\mathrm{n}$ & $\mathbf{F e}$ mean & se & Ca mean & se & Mn mean & se & $\mathbf{P}$ mean & se & Na mean & se \\
\hline \multicolumn{12}{|l|}{ Tax. section } \\
\hline ACUTIFOLIA & 20 & $.062 \mathrm{c}$ & .025 & $.227 \mathrm{a}$ & .032 & $.020 \mathrm{a}$ & .003 & $.064 \mathrm{a}$ & .008 & $.035 \mathrm{a}$ & .003 \\
\hline CUSPIDATA & 25 & $.142 b$ & .056 & $.190 \mathrm{~b}$ & .038 & $.006 \mathrm{~b}$ & .001 & $.038 \mathrm{~b}$ & .004 & $.062 \mathrm{a}$ & .008 \\
\hline SPHAGNUM & 11 & $.124 \mathrm{c}$ & .043 & $.251 \mathrm{a}$ & .042 & $.013 \mathrm{c}$ & .003 & $.047 \mathrm{~b}$ & .008 & $.037 \mathrm{a}$ & .004 \\
\hline \multicolumn{12}{|l|}{ Microsite } \\
\hline Hollow & 15 & $.216 \mathrm{a}$ & .090 & $.227 \mathrm{a}$ & .060 & $.006 \mathrm{a}$ & .002 & $.034 a$ & .003 & $.065 \mathrm{a}$ & .012 \\
\hline Hummock & 11 & $.051 \mathrm{~b}$ & .019 & $.165 b$ & .027 & $.016 \mathrm{~b}$ & .005 & $.048 b$ & .006 & $.034 \mathrm{a}$ & .005 \\
\hline Lawn & 30 & $.078 \mathrm{~b}$ & .023 & $.228 \mathrm{a}$ & .026 & $.014 \mathrm{a}$ & .002 & $.057 \mathrm{a}$ & .007 & $.044 a$ & .004 \\
\hline \multicolumn{12}{|l|}{ Peatland } \\
\hline Björnmyran & 7 & .508 & .156 & .521 & .073 & .029 & .006 & .040 & .004 & .041 & .008 \\
\hline Kroktjärnmyran & 9 & .051 & .020 & .172 & .041 & .012 & .004 & .083 & .011 & .029 & .003 \\
\hline Sjulsmyran & 8 & .115 & .021 & .137 & .014 & .005 & .001 & .042 & .007 & .039 & .006 \\
\hline Stor-Åmyran & 11 & .032 & .007 & .137 & .024 & .012 & .003 & .050 & .013 & .065 & .014 \\
\hline Stor-Vidmyran & 1 & .039 & - & .199 & - & - & - & .027 & - & .096 & - \\
\hline Torsmyran & 10 & .036 & .014 & .236 & .051 & .006 & .001 & .035 & .003 & .056 & .012 \\
\hline Våtömyran & 10 & .046 & .007 & .170 & .016 & .013 & .003 & .046 & .008 & .045 & .006 \\
\hline Statistics* & df & W-X2 & $P$ & W-X2 & $P$ & $\mathrm{~W}-\mathrm{X} 2$ & $P$ & W-X2 & $P$ & $\mathrm{~W}-\mathrm{X} 2$ & $P$ \\
\hline Tax. section & 2 & 7 & .026 & 15 & $<.001$ & 40 & $<.001$ & 18 & $<.001$ & 1 & .735 \\
\hline Microsite & 2 & 17 & $<.001$ & 16 & $<.001$ & 9 & .011 & 15 & .001 & 4 & .121 \\
\hline Peatland & $5-6$ & 126 & $<.001$ & 59 & $<.001$ & 49 & $<.001$ & 36 & $<.001$ & 21 & .002 \\
\hline Transformation & & $\ln$ & & $\ln$ & & $\ln$ & & $\ln (\ln )$ & & $\ln$ & \\
\hline
\end{tabular}

Full data are available in the Dryad data-repository. Statistics refer to individual Generalised Linear Models with main effects only for each inorganic element. Df = degree of freedom, W-X2 = Wald-Chi square. Different letters (a, b, c) indicate statistically significant differences between microsites or between taxonomic sections. Transformation indicates how data were transformed to achieve normal distribution and homogeneity of variances prior to statistical analyses

carbohydrate compositions were mainly determined by environmental factors and micro-topographic variation within the peatland. In contrast, the dominant control on carbohydrate composition was Sphagnum phylogeny, i.e. the taxonomic sections within the genus Sphagnum. The above implies that Sphagnum chemistry can be separated into an environmentally dependent, variable group of compounds and an environmentally independent, phylogenetically conserved group of compounds.

That environment affects inorganic elements and non-carbohydrates more than carbohydrates seems in line with evidence from fertilisation and water-table experiments, although experimental support for peatlands remains scarce. Nitrogen deposition has been shown to alter Sphagnum nutrient stoichiometry (Bragazza et al. 2004; Limpens et al. 2011) and phenolic constituents (Bragazza and Freeman 2007). Likewise, drier surface conditions associated with water table drawdown enhanced both $\mathrm{N}$ and $\mathrm{P}$ concentrations in Sphagnum (Straková et al. 2010). Finally, comparisons of plant litters across latitudinal climate gradients suggest significant differences in N, P and phenolic constituents for a wide number of litter types (Aerts 1997, Bragazza and Gerdol 2002), including Sphagnum (Dorrepaal et al. 2005). In contrast to nutrient concentrations and phenolic constituents, evidence for direct environmental effects on carbohydrate polymers in Sphagnum remains incidental: changes in carbohydrate monomers, such as glucose, have been observed in response to drought (Straková et al. 2010) and $\mathrm{CO}_{2}$ enhancement (Van der Heijden et al. 2000). On account of the above it seems reasonable to assume that environmental factors control inorganic elements and 

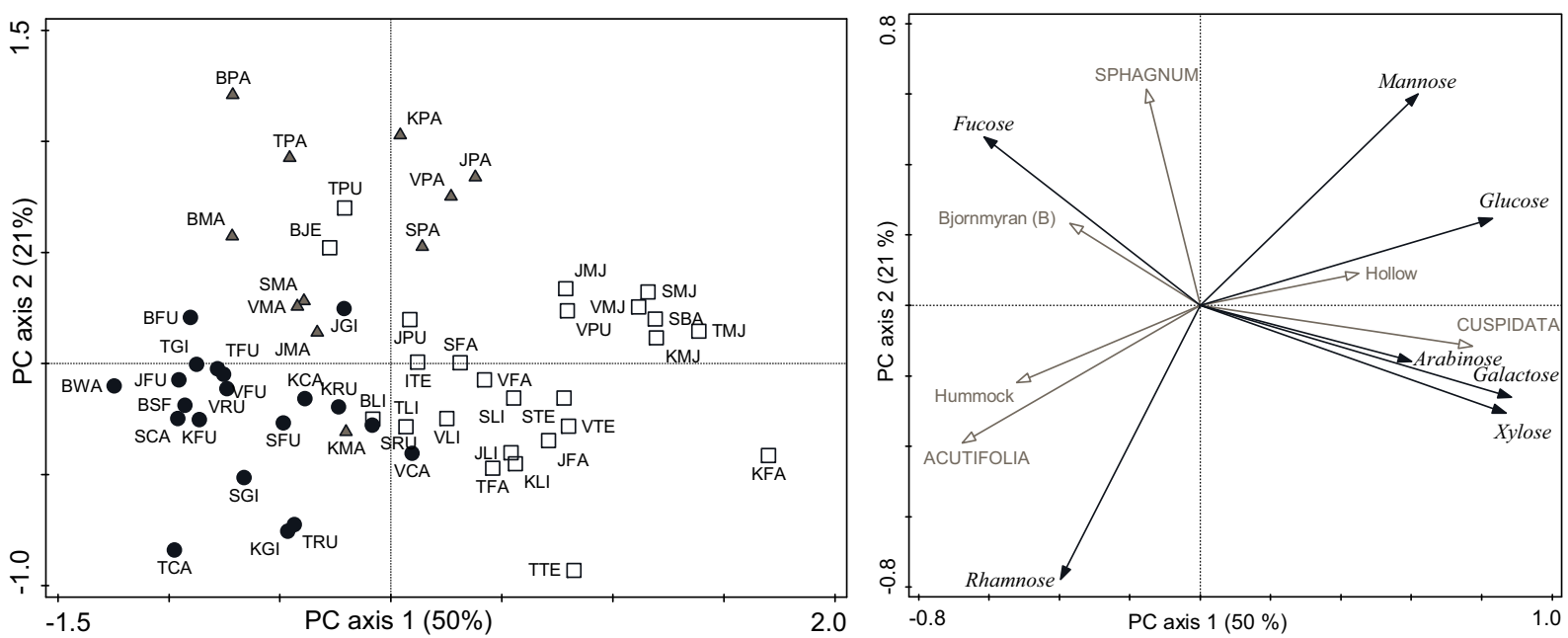

Fig. 3 PC ordination based on the contents of seven carbohydrate monomers of 56 Sphagnum samples. Together, the four ordination axes explained $90 \%$ of the total variation in carbohydrates among samples, with $71 \%$ being explained by the first two axes. Left panel shows the position of all Sphagnum samples in ordination space. Open squares $=$ samples from the taxonomic CUSPIDATA

section, solid grey triangles $=$ section SPHAGNUM and solid black circles $=$ section ACUTIFOLIA. See Fig. 2 and Table 2 for explanation of sample codes. Right panel shows the correlation between the PC axes and the carbohydrate monomers (black arrows) and those supplementary variables (grey arrows) with a correlation coefficient $\leq-0.4$ or $\geq+0.4$ with $\mathrm{PC} 1$ and/or PC2

secondary metabolites (phenolics or metabolic carbohydrates) rather than the primary ones, especially the cellwall carbohydrate polymers as they form the majority of plant biomass and thus cannot be replaced, only produced. However, the little evidence there is, is not in agreement with this assumption: Straková et al. (2010) reported changes in glucose concentrations associated with cell-wall carbohydrate polymers, whereas Van der Heijden et al. (2000) reported changes in glucose concentrations associated with metabolic carbohydrates. Disentangling the contribution of environment from that of phylogeny would require a more extensive experimental approach, coupled with chemical characterisation.

The effect of environment on Sphagnum chemistry can be either a direct result of abiotic drivers, or an indirect result mediated by biotic interactions with accompanying plant species (Table S1) or microorganisms showing the same preference for peatland type or microsite. Part of the variation in microsite was shared with phylogeny (Fig. 5), as only species of ACUTIFOLIA occurred on hummocks and CUSPIDATA occurred in hollows (Table 2). Nevertheless, since representatives of all three taxonomic sections shared the intermediate lawn microhabitat, it seems unlikely that the variance partitioning procedure overestimated the pure phylogenetic signal by more than a few \% (Fig. 5).

\section{Elements}

The patterns we found in base cations $(\mathrm{Mg}, \mathrm{Ca})$ and metals (Mn, Al, Fe) were mostly correlated to general peatland type (Table 1), varying mostly along the fen-bog gradient and direct mineral soil contribution within the peatland margin. This pattern is similar to what is found along hydro-geochemical acidity-alkalinity gradients for a wide range of peatlands (Vitt et al. 1990; Bragazza and Gerdol 2002) and illustrates the strong association with geo-hydrological variables such as catchment mineralogy, catchment to peatland areal ratio, the hydrological isolation from mineral sources and distance to the sea (Mullen et al. 2000). Base cations and metal ions as Mn serve important functions in peatlands, strongly determining bryophyte distributions and vascular plant diversity (Bridgham et al. 1996; Bragazza and Gerdol 2002).

The patterns in major plant nutrients $(\mathrm{N}, \mathrm{P}, \mathrm{K})$ but also $\mathrm{S}$ and $\mathrm{Na}$ in the Sphagnum mosses partly covaried with the acidity-alkalinity gradient, with values being generally higher in fens than in bogs, as also observed by other authors (Wheeler and Proctor 2000). The patterns seemed to be explained by a combination of peatland type, specific species or species-combinations and/or position (margin, centre, hollow) within the peatland. The low nutrient 
Table 4 Sample sizes (n), untransformed mean contents (\% dw) and standard errors (se) of 5 carbohydrate monomers aggregated per taxonomic section, microsite and peatland. Only those carbohydrates with a strong correlation with one of the four PCA ordination axes (Fig. 3) and low correlation with other constituents were shown. Taken together these five carbohydrate monomers represent between $87 \%$ and $89 \%$ of the total carbohydrate content per Sphagnum sample

\begin{tabular}{|c|c|c|c|c|c|c|c|c|c|c|c|}
\hline & $\mathbf{n}$ & Rham mean & se & Fuc mean & se & Man mean & se & Gluc mean & se & Gal mean & se \\
\hline \multicolumn{12}{|l|}{ Tax. section } \\
\hline ACUTIFOLIA & 20 & $3.84 \mathrm{a}$ & .07 & $.45 \mathrm{a}$ & .01 & $3.12 \mathrm{a}$ & .05 & $23.22 \mathrm{a}$ & .33 & $6.31 \mathrm{a}$ & .13 \\
\hline CUSPIDATA & 25 & $3.26 \mathrm{~b}$ & .08 & $.52 b$ & .02 & $3.59 \mathrm{~b}$ & .09 & $27.21 b$ & .38 & $8.15 b$ & .22 \\
\hline SPHAGNUM & 11 & $3.17 \mathrm{c}$ & .07 & $.41 \mathrm{a}$ & .02 & $3.90 \mathrm{~b}$ & .20 & $25.76 b$ & .40 & $6.37 \mathrm{a}$ & .17 \\
\hline \multicolumn{12}{|l|}{ Microsite } \\
\hline Hollow & 15 & $3.10 \mathrm{a}$ & .10 & $.51 \mathrm{a}$ & .02 & $3.49 \mathrm{a}$ & .12 & $27.54 \mathrm{a}$ & .58 & $7.77 \mathrm{a}$ & .28 \\
\hline Hummock & 11 & $3.81 \mathrm{~b}$ & .08 & $.44 a$ & .01 & $3.14 \mathrm{a}$ & .09 & $22.43 b$ & .34 & $6.16 \mathrm{~b}$ & .21 \\
\hline Lawn & 30 & $3.50 \mathrm{~b}$ & .08 & $.47 \mathrm{a}$ & .02 & $3.61 \mathrm{a}$ & .11 & $25.61 \mathrm{c}$ & .29 & $7.18 \mathrm{a}$ & .23 \\
\hline \multicolumn{12}{|l|}{ Peatland } \\
\hline Björnmyran & 7 & 3.31 & .22 & .42 & .02 & 3.22 & .17 & 24.28 & .68 & 5.65 & .19 \\
\hline Kroktjärnmyran & 9 & 3.56 & .16 & .53 & .04 & 3.60 & .20 & 25.39 & .93 & 7.22 & .34 \\
\hline Sjulsmyran & 8 & 3.27 & .11 & .46 & .03 & 3.61 & .22 & 25.53 & .77 & 7.19 & .29 \\
\hline Stor-Åmyran & 11 & 3.48 & .12 & .48 & .02 & 3.54 & .17 & 26.15 & .83 & 7.63 & .40 \\
\hline Stor-Vidmyran & 1 & 3.44 & . & .44 & & 3.30 & & 26.88 & & 8.62 & \\
\hline Torsmyran & 10 & 3.57 & .20 & .48 & .03 & 3.32 & .13 & 24.83 & .69 & 7.24 & .51 \\
\hline Våtömyran & 10 & 3.45 & .11 & .47 & .02 & 3.60 & .16 & 26.24 & .83 & 7.29 & .31 \\
\hline Statistics & df & W-X2 & $P$ & W-X2 & $P$ & W-X2 & $P$ & W-X2 & $P$ & W-X2 & $P$ \\
\hline Tax. section & 2 & 24 & $<.001$ & 35 & $<.001$ & 23 & $<.001$ & 13 & .002 & 69 & $<.001$ \\
\hline Microsite & 2 & 9 & .010 & 3 & .242 & 3 & .211 & 12 & .003 & 7 & .026 \\
\hline Peatland & $5-6$ & 3 & .796 & 21 & .002 & 7 & .292 & 11 & .097 & 44 & $<.001$ \\
\hline Transformations & & none & & $\ln$ & & $\ln (\ln )$ & & none & & $\ln (\ln )$ & \\
\hline
\end{tabular}

Full data are available in the Dryad data-repository. Rham = rhamnose, Fuc = fucose, Man = mannose, Gluc = glucose, Gal = galactose . Statistics refer to individual Generalised Linear Models with main effects only for each carbohydrate. Df $=$ degree of freedom, W-X2 = WaldChi square. Different letters ( $a, b, c)$ indicate statistically significant differences between microsites or between taxonomic sections. Transformation indicates how data were transformed to achieve normal distribution and homogeneity of variances prior to statistical analyses

concentrations in hollow species from the peatland centre potentially reflects the lower nutrient retention capacity of hollows (Bragazza et al. 2004), the prevailing direction of water flow and dissolved nutrients from hollows to lawns and hummocks in more continental climates (Eppinga et al. 2010) or, alternatively, extra nutrient relocation from deeper depths by co-occurring vascular plant species in lawns and hummocks (Malmer et al. 1992; Malmer et al. 2003). As nutrient concentrations in Sphagnum plant material co-determine its degradability and speed of mineralisation (Damman 1988; Limpens and Berendse 2003; Straková et al. 2012), differences in nutrient concentrations in Sphagnum may have direct implications for mineralisation rates and nutrient cycling in peatlands.
Non-carbohydrates: aromatic and aliphatic compounds

Peatland explained the largest part of the variation in both aromatic and aliphatic compounds in Sphagnum, again with most variation connected to the fen-bog gradient. Nevertheless, some aromatics (phenolics) and aliphatic compounds (lipids) seemed to be restricted to some species or taxonomic sections. Many aromatic and aliphatic compounds are among those compounds most resistant to decay (Minderman 1968). This is also reflected in Sphagnum peat as the relative contributions of the aromatic and aliphatic fractions increase with increased peat decomposition (Bohlin et al. 1989; Nordén et al. 1992). In highly decomposed Sphagnum peat the aromatic and aliphatic carbon make up a major portion of the finest particle size fraction (Nordén et al. 


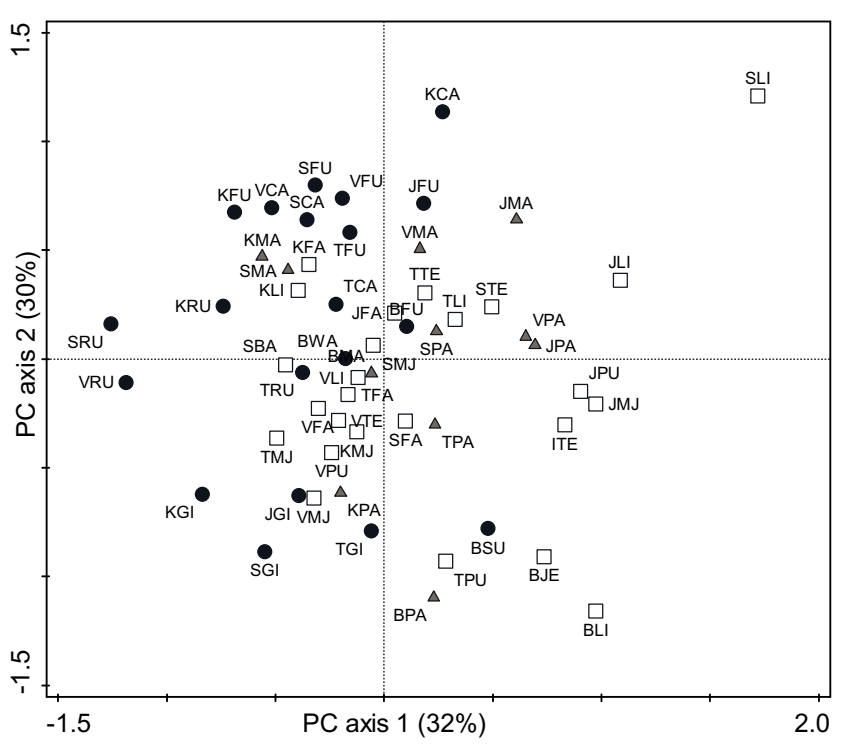

Fig. 4 PC ordination based on the contents of 18 noncarbohydrate fragments (F) from pyrolysis of 56 Sphagnum samples. Together, the four ordination axes explained $81 \%$ of the total variation in non-carbohydrates among samples, with $62 \%$ being explained by the first two axes. Left panel shows the position of all Sphagnum samples in ordination space. Open squares = samples from the taxonomic CUSPIDATA section, solid grey triangles $=$

1992), i.e. the most decomposed material. The results from this study suggest that the differences in the concentrations of many of these compounds between peat profiles might be more related to environmental controls (peatland type and micro topography) than phylogeny.

Most phenolics in Sphagnum are associated with polyphenols coating the cell wall surface offering both structural support and physical protection against decomposition, similar to lignin in many other plant genera (Tsuneda et al. 2001). These lignin-like phenolic networks may decompose into soluble monomers such as sphagnum acid (Rudolph and Samland 1985; Williams et al. 1998) that inhibit the activity of extracellular enzymes under anaerobic conditions (Verhoeven and Liefveld 1997; Freeman et al. 2001) together with other low-molecular weight soluble phenolics excreted by living cells (Rasmussen et al. 1995). Consequently, environmentally induced variation in the amount and concentration of these phenolics may have consequences for both carbon accumulation and mineralisation rates.

Most lipids in Sphagnum, as in other bryophytes, are either an insoluble component of cell-wall membranes or are part of cell solutes where they serve an energy storage function (Longton 1988). In living Sphagnum,

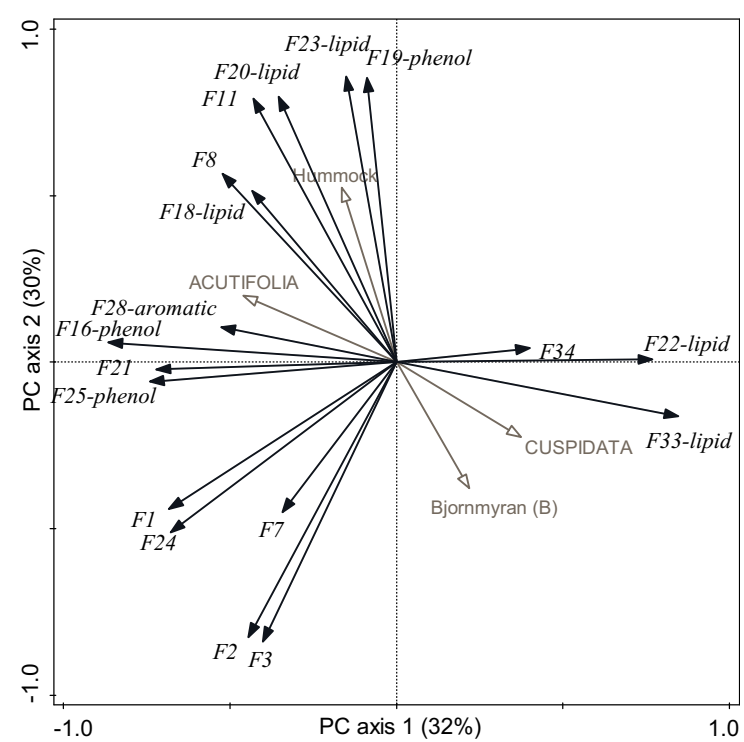

section SPHAGNUM and solid black circles $=$ section ACUTIFOLIA. See Fig. 2 and Table 2 for explanation of sample codes. Right panel shows the correlation between the PC axes and the non-carbohydrates (black arrows) and those supplementary variables (grey arrows) with a correlation coefficient $\leq-0.4$ or $\geq$ +0.4 with PC1 and/or PC2

the largest concentrations of total lipids are soluble (Karunen and Ekman 1982; Karunen and Salin 1982) and vary seasonally, with highest concentrations generally reached just before winter. In contrast, the insoluble, polymerised cell-wall lipids that are preserved in peat profiles have low concentrations in living tissue (Karunen and Salin 1982). As we sampled living tissue, most of the variation in lipid content between Sphagnum samples is likely associated with the soluble storage lipids, rather than the cell-wall lipids.

\section{Carbohydrates}

In contrast to both inorganic elements and non-carbohydrates, most variation in carbohydrates was explained by Sphagnum taxonomy, implying that carbohydrate composition is phylogenetically conserved. In addition, taxonomic group shared considerable variation with microsite, illustrative of the correlation between Sphagnum phylogeny and position along the hummock-hollow gradient (Shaw 2000; Johnson et al. 2014). The central role of Sphagnum species in maintaining micro-topography is illustrated by Hájek (2009). He showed that species occupying elevated hummocks combined slow decomposition rates with sufficient 
Table 5 Sample sizes (n), relative integration sums multiplied by 1000 ) and standard errors (se) of 5 non-carbohydrate polymer fragments (F) from pyrolysis aggregated per taxonomic section, microsite unit and peatland. Only those non-carbohydrates with a strong correlation with one of the four PCA ordination axes
(Fig. 4) and low correlation with other constituents were shown. Taken together these five non-carbohydrates represent between 21 and $26 \%$ of the total non-carbohydrate content per Sphagnum sample

\begin{tabular}{|c|c|c|c|c|c|c|c|c|c|c|c|}
\hline & $\mathbf{n}$ & F2 mean & $\mathrm{se}$ & F16 mean & se & F20 mean & se & F19 mean & se & F33 mean & se \\
\hline \multicolumn{12}{|l|}{ Tax. section } \\
\hline ACUTIFOLIA & 20 & $95.3 \mathrm{a}$ & 3.8 & $25.2 \mathrm{a}$ & .6 & $8.9 \mathrm{ab}$ & .2 & $12.0 \mathrm{a}$ & .2 & $8.8 \mathrm{a}$ & .4 \\
\hline CUSPIDATA & 25 & $97.8 \mathrm{~b}$ & 3.0 & $21.2 b$ & .6 & $8.5 b$ & .2 & $11.1 \mathrm{a}$ & .2 & $10.9 \mathrm{~b}$ & .4 \\
\hline SPHAGNUM & 11 & $87.4 \mathrm{c}$ & 3.2 & $22.9 b$ & .7 & $8.2 \mathrm{a}$ & .3 & $11.2 \mathrm{a}$ & .2 & $10.3 b$ & .4 \\
\hline \multicolumn{12}{|l|}{ Microsite } \\
\hline Hollow & 15 & $97.0 \mathrm{a}$ & 4.9 & $20.9 a$ & .9 & $8.3 \mathrm{a}$ & .3 & $11.1 \mathrm{a}$ & .3 & $11.1 \mathrm{a}$ & .4 \\
\hline Hummock & 11 & $81.7 \mathrm{~b}$ & 1.8 & $24.4 \mathrm{a}$ & .7 & $9.4 \mathrm{~b}$ & .2 & $9.2 \mathrm{~b}$ & .2 & $9.2 \mathrm{a}$ & .4 \\
\hline Lawn & 30 & $94.9 \mathrm{a}$ & 2.4 & $23.0 \mathrm{a}$ & .5 & $8.5 \mathrm{a}$ & .2 & $9.8 \mathrm{a}$ & .1 & $9.9 \mathrm{a}$ & .4 \\
\hline \multicolumn{12}{|l|}{ Peatland } \\
\hline Björnmyran & 7 & 100.7 & 5.0 & 21.4 & 1.0 & 7.4 & .4 & 10.8 & .4 & 11.4 & .6 \\
\hline Kroktjärnmyran & 9 & 98.2 & 5.0 & 25.3 & 1.0 & 9.4 & .3 & 11.9 & .4 & 8.8 & .5 \\
\hline Sjulsmyran & 8 & 86.9 & 5.2 & 20.2 & .9 & 8.4 & .3 & 11.5 & .3 & 10.4 & .5 \\
\hline Stor-Åmyran & 11 & 89.7 & 5.4 & 23.2 & .9 & 9.1 & .3 & 11.5 & .3 & 9.6 & .8 \\
\hline Stor-Vidmyran & 1 & 97.3 & & 20.5 & & 7.9 & & 10.7 & & 15.3 & \\
\hline Torsmyran & 10 & 97.5 & 3.6 & 23.3 & .8 & 8.3 & .3 & 11.3 & .3 & 10.2 & .4 \\
\hline Våtömyran & 10 & 97.0 & 5.4 & 24.1 & 1.0 & 8.8 & .2 & 11.4 & .3 & 9.7 & .5 \\
\hline Statistics & df & W-X2 & $P$ & W-X2 & $P$ & W-X2 & $P$ & W-X2 & $P$ & W-X2 & $P$ \\
\hline Tax. section & 2 & 30 & $<.001$ & 25 & $<.001$ & 5 & .078 & 1 & .584 & 14 & .001 \\
\hline Microsite & 2 & 48 & $<.001$ & 4 & .136 & 18 & $<.001$ & 46 & $<.001$ & 4 & .156 \\
\hline Peatland & 6 & 17 & .011 & 34 & $<.001$ & 39 & $<.001$ & 6 & .013 & 32 & $<.001$ \\
\hline Transformations & & none & & $\ln$ & & $\ln (\ln )$ & & none & & $\ln (\ln )$ & \\
\hline
\end{tabular}

Full data are available in the Dryad data-repository. F16, 19 are characteristic of phenolic compounds, F20 of lipids, F2 and F33 are pyrolysis fragments of unknown origin (Table S2). Statistics refer to individual Generalised Linear Models with main effects only for each noncarbohydrate fragment. Df = degree of freedom, W-X2 = Wald-Chi square. Different letters $(\mathrm{a}, \mathrm{b}, \mathrm{c})$ indicate statistically significant differences between microsites or between taxonomic sections. Transformation indicates how data were transformed to achieve normal distribution and homogeneity of variances prior to statistical analyses

production to offset the faster production and faster decomposition of hollow dwelling species, thus maintaining the relative difference in elevation between these microsites. The apparent trade-off between poor degradability and high production between hummock and hollow species has been attributed to differences in resource partitioning over metabolic and structural carbohydrates (Turetsky et al. 2008). In our work we cannot make a similar distinction, as our focus on carbohydrate monomers rather than pyrolysis fragments means our patterns are dominated by the composition of the carbohydrates making up most of the plant mass: the structural carbohydrates rather than the metabolic ones. Nevertheless in our work species from the ACUTIFOLIA section, known for their position at the higher end of the hummock-hollow gradient (Anderson et al. 1995) were distinguishable from the CUSPIDATA section, known for their position at the lower end of the hummock-hollow gradient (Anderson et al. 1995) by the their $\mathrm{C}$ allocation to main structural carbohydrate polymers, hemicellulose and pectin in particular. In our study CUSPIDATA were characterised by high contents of monomers that make up hemicellulose, notably xylose, whereas ACUTIFOLIA had higher contents of rhamnose, component of rhamnogalacturonan, a type of highly branched pectin. Species from SPHAGNUM were mainly characterised by their low concentrations of rhamnose and high concentrations of mannose, also a monomer from hemicellulose. Consequently, our results point towards a phylogenetic signal in the composition 


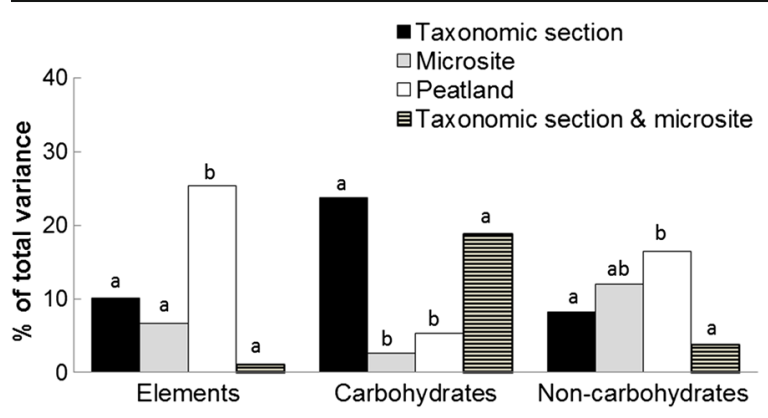

Fig. 5 Percentage of total variation within three functional chemistry types in Sphagnum uniquely explained by taxonomic section, microsite and peatland as well as the variation shared by taxonomic section and microsite (the only combination that explained more than $5 \%$ of the variation within one of the chemistry types). For other shared variation see Table S3). Variance partitioning was based on separate RDAs, one for each functional chemistry type (Table S3). Statistical differences in explained variation between chemical types were assessed for each driver separately using $X^{2}$ tests. Different letters above each column show statistical significant differences between the columns $P<0.05$, based on Bonferroni corrected pairwise comparisons

of cell-wall carbohydrates that coincides with the position of the species and sections along the hummockhollow gradient.

Taken together, the correlations between: I) Sphagnum taxonomy and the position of the sections and species along the hummock-hollow gradient (Shaw 2000; Johnson et al. 2014); II) the position along the hummock-hollow gradient and litter degradability (Johnson and Damman 1991, Bengtsson et al. 2016) and III) Sphagnum taxonomy and structural carbohydrate composition (this study), implies that the differences in degradability between Sphagnum species are at least in part a function of their carbohydrate chemistry. Cell-wall carbohydrates have been shown to play a role in the low-degradability of Sphagnum as a genus (Bohlin et al. 1989; Turetsky et al. 2008; Hájek et al. 2011). For example, Bohlin et al. (1989) compared concentrations of structural carbohydrate monomers after acid digestion of fresh litter, lightly decomposed peat and highly decomposed peat of both Sphagnum and sedges (Carex). They showed that glucose concentrations in highly decomposed Sphagnum peat remained near that to fresh Sphagnum plant litter, whereas glucose concentrations in sedge material significantly decreased. Using in vitro incubations of Sphagnum material chemically stripped from all non-carbohydrates, Hájek et al. (2011) also argued for a carbohydrate-determined recalcitrance of Sphagnum litter. They suggest that Sphagnum carbohydrate polymers have a similar role in litter decomposition recalcitrance as lignin in many vascular plants. To what extent the same agents responsible for low degradability of Sphagnum as a genus are indeed responsible for the differences in degradability observed between species and sections (Bengtsson et al. 2016) remains to be determined. However, the close associations between Sphagnum phylogeny, microtopography and carbohydrate chemistry suggest that differences in carbohydrate chemistry may have driven speciation in Sphagnum, contributing to the emergence of micro-habitats, and thus micro-topography, in peatlands.

Implications for peatland processes

The high variation of inorganic elements and noncarbohydrates along environmental gradients suggest that the amount and concentration of these compounds will be the first to respond when the environment changes. Likewise, the low variation of carbohydrate composition along environmental gradients suggests low responsiveness to changes in environment, as long as species-replacement occurs within the same taxonomic section. For example, as availability of nutrients change, low-productive species, such as S. balticum, may become replaced by more productive species, such as S. fallax (section CUSPIDATA, Gunnarsson 2005). But, as long as species replacement occurs within taxonomic section, the consequences for peat accumulation may be limited as microtopography, and thereby overall hydrologic functioning, will be maintained (Bohlin et al. 1989; Belyea and Clymo 2001). Assuming our inferences above are correct, the phylogenetically conserved carbohydrate chemistry thus likely reinforces the strong control exerted by Sphagnum species on their environment, contributing to the resilience of peatlands to environmental change (Belyea 2009; Turetsky et al. 2012; Heijmans et al. 2013).

\section{Conclusions}

Our study shows that the elemental and noncarbohydrate compositions of Sphagnum are mainly determined by environmental factors and microtopographic variation within the peatland. The dominant control on carbohydrate composition is Sphagnum phylogeny, i.e. the taxonomic sections within the genus Sphagnum. The separation into an environmentally 
dependent, variable group of compounds and an environmentally independent, phylogenetically conserved group of compounds has important implications both for understanding patterns in and for upscaling of spatially variable ecosystem processes such as carbon sequestration, nutrient cycling and greenhouse gas emissions. Our study is a first step towards understanding the interactions between chemical traits, phylogeny and environment. Further separating these interactions and the consequences for nutrient and carbon cycling, however, requires a combination of targeted experiments and modelling.

Acknowledgements We thank Christina Röckner for her skilful experimental work. Financial support for this project was provided by the National Energy Administration, Sweden (NEA) through grant 216,100 to MN. We thank Tim Moore and two anonymous reviewers for their help in improving the manuscript.

Compliance with ethical standards We are not aware of any conflicts of interest or ethical issues regarding the data collection or paper content.

Open Access This article is distributed under the terms of the Creative Commons Attribution 4.0 International License (http:// creativecommons.org/licenses/by/4.0/), which permits unrestricted use, distribution, and reproduction in any medium, provided you give appropriate credit to the original author(s) and the source, provide a link to the Creative Commons license, and indicate if changes were made.

\section{References}

Aerts R (1997) Climate, leaf litter chemistry and leaf litter decomposition in terrestrial ecosystems: a triangular relationship. Oikos 79:439-449

Ågren GI, Bosatta E (1996) Quality: a bridge between theory and experiment in soil organic matter studies. Oikos 76:522-528

Alexandersson H, Karlström C, Larsson-Mccann S (1991). Temperature and precipitation in Sweden 1961-1990. Reference normals. Meteorologi 81, Norrköping, Sweden: Swedish Meteorological and Hydrological Institute (SMHI) (in Swedish)

Anderson AS, Davis RB, Janssens JA (1995) Relationships of bryophytes and lichens to environmental gradients in Maine peatlands. Vegetatio 120:147-259

Belyea LR (2009) Nonlinear dynamics of peatlands and potential feedbacks on the climate system. In: Baird AJ, Belyea LR, Comas X, Reeve AS, Slater LD (eds) Carbon cycling in northern peatlands. American Geophysical Union, Washington DC. doi:10.1029/2008GM000829

Belyea LR, Baird AJ (2006) Beyond the limits to peat bog growth: cross-scale feedback in peatland development. Ecol Mon 76: 299-322
Belyea LR, Clymo RS (2001) Feedback control of the rate of peat formation. Proc Royal Soc London B: Biol Sci 268:13151321

Bengtsson F, Granath G, Rydin H (2016) Photosynthesis, growth, and decay traits in Sphagnum - a multispecies comparison. Ecol Evol 6(10):3325-3341

Bohlin E, Hämäläinen M, Sundén T (1989) Botanical and chemical characterization of peat using multivariate methods. Soil Sci 147:253-263

Boon JJ, Dupont L, De Leeuw JW (1986) Characterization of a peat bog profile by Curie point pyrolysis-mass spectrometry combined with multivariate analysis and by pyrolysis gas chromatography-mass spectrometry. In: Fuchsman CH (ed) Peat and Water. Elsevier, Amsterdam, pp 215-239

Braak CJF, Šmilauer P (2012) CANOCO reference manual and user's guide: software for ordination (version 5.0). Wageningen: Biometris.

Bracewell JM, Robertson GW, Williams BL (1980) Pyrolysismass spectrometry studies of humification in a peat and peaty podzol. J Anal Appl Pyrolysis 2:53-62

Bradford MA, Jones TH, Bardgett RD, Black HIJ, Boag B, Bonkowski M, Cook R, Eggers T, Gange AC, Grayston SJ et al (2002) Impacts of soil faunal community composition on model grassland ecosystems. Science 298:615-618

Bragazza L (1997) Sphagnum niche diversification in two oligotrophic mires in the southern Alps of Italy. Bryologist 100: 507-515

Bragazza L, Freeman C (2007) High nitrogen availability reduces polyphenol content in Sphagnum peat. Sci Tot Env 377:439 443

Bragazza L, Gerdol R (2002) Are nutrient availability and acidityalkalinity gradients related in Sphagnum-dominated peatlands? J Veg Sci 13:473-482

Bragazza L, Tahvanainen T, Kutnar L, Rydin H, Limpens J, Hàjek M, Grosvernier P, Hansen I, Iacumin P, Gerdol R (2004) Nutritional constraints in ombrotrophic Sphagnum subject to increasing levels of atmospheric nitrogen deposition in Europe. New Phytol 163:609-616

Bragazza L, Limpens J, Gerdol R, Grosvernier P, Hájek M, Hajkova P, Lacumin P, Kutnar L, Rydin H, Tahvanainen T (2005) Nitrogen content and d15N signature of ombrotrophic Sphagnum plants in Europe: to what extent is the increasing atmospheric $\mathrm{N}$ deposition altering the N-status of nutrientpoor mires? GCB 11:106-114

Bridgham SD, Pastor J, Janssens JA, Chapin C, Malterer TJ (1996) Multiple limiting gradients in peatlands: a call for a new paradigm. Wetlands 16:45-65

Clymo RS (1963) Ion exchange in Sphagnum and its relation to bog ecology. Ann Bot 27:309-324

Clymo RS (1965) Experiments on breakdown of Sphagnum in two bogs. J Ecol 53:747-758

Coley PD, Bryant JP, Chapin FS III (1985) Resource availability and plant anti-herbivore defense. Science 230:895-899

Damman AWH (1988) Regulation of nitrogen removal and retention in Sphagnum bogs and other peatlands. Oikos 51:291305

Dorrepaal E., Cornelissen JHC, Aerts R, Wallen B, van Logetestijn RSP (2005) Are growth forms consistent predictors of leaf litter quality and decomposability across peatlands along a latitudinal gradient? J Ecol 93:817-828 
Eppinga MB, Rietkerk M, Belyea LR, Nilsson MB, Ruiter PCD, Wassen MJ (2010) Resource contrast in patterned peatlands increases along a climatic gradient. Ecology 91:2344-2355

Eurola S, Hicks S, Kaakinen E (1984) Key to Finnish mire types. In: Moore PD (ed) European mires. Academic Press, London

Freeman C, Ostle N, Kang H (2001) An enzymic 'latch' on a global carbon store. Nature 409:149-149

Gignac LD (1992) Niche structure, resource partitioning and species interactions of mire bryophytes relative to climatic and ecological gradients in western Canada. Bryologist 95:406418

Grime JP, Rincon ER, Wickerson BE (1990) Bryophytes and plant strategy theory. Bot J Linn Soc 104:175-186

Gunnarsson U (2005) Global patterns of Sphagnum productivity. J Bryol 27:269-279

Hájek T (2009) Habitat and species controls on Sphagnum production and decomposition in a mountain raised bog. Bor Env Res 14:947-958

Hájek T, Ballance S, Limpens J, Zijlstra MJ, Verhoeven JTA (2011) Cell wall polysaccharides play an important role in decay resistance of Sphagnum and actively depressed decomposition in vitro. Biogeochemistry 103:45-57

Hayward PM, Clymo RS (1982) Profiles of water content and pore size in Sphagnum and peat, and their relation to peat bog ecology. Proc Roy Soc London B Biol Sci 215:299-325

Heijmans MM, Knaap YA, Holmgren M, Limpens J (2013) Persistent versus transient tree encroachment of temperate peat bogs: effects of climate warming and drought events. GCB 19:2240-2250

IPCC (2013) Long-term climate change: projections, commitments and irreversibility. In: Stocker TF, Qin D, Plattner GK, Tignor M, Allen SK, Boschung J, Nauels A, Xia Y, Bex V, Midgley PM (eds) Climate Change 2013: The Physical Science Basis Contribution of Working Group I to the Fifth Assessment Report of the Intergovernmental Panel on Climate Change. Cambridge University Press, Cambridge

Johnson LC, Damman AWH (1991) Species-controlled Sphagnum decay on a South Swedish raised bog. Oikos 61: 234-242

Johnson MG,Granath G, Tahvanainen T, Pouliot R, Stenøien HK, Rochefort L, Rydin H, Shaw AJ (2014) Evolution of niche preference in Sphagnum peat mosses. Evolution 69:90-103

Karunen P, Ekman R (1982) Age-dependent content of polymerized lipids in Sphagnum fuscum. Physiol Plant 54:162-166

Karunen P, Salin M (1982) Seasonal changes in lipids of photosynthetically active and senescent parts of Sphagnum fuscum. Lindbergia 8:35-44

Laing CG, Granath G, Belyea LR, Allton KE, Rydin H (2014) Tradeoffs and scaling of functional traits in Sphagnum as drivers of carbon cycling in peatlands. Oikos 123:817-828

Laudon H, Taberman I, Ågren A, Futter M, Ottosson-Löfvenius M, Bishop K (2013) The Krycklan catchment study-a flagship infrastructure for hydrology, biogeochemistry, and climate research in the boreal landscape. Wat Resource Res 49:7154-7158

Lepš J, Šmilauer P (2003) Multivariate analysis of ecological data using Canoco. Cambridge University Press, Cambridge

Limpens J, Berendse F (2003) How litter quality affects mass loss and N loss from decomposing Sphagnum. Oikos 103:537547
Limpens J, Granath G, Gunnarsson U, Aerts R, Bayley S, Bragazza L, Bubier J, Buttler A, Van den Berg LJL, Francez A-J et al (2011) Climatic modifiers of the response to $\mathrm{N}$ deposition in peat-forming Sphagnum mosses: a metaanalysis. New Phyt 191:496-507

Loisel J, Yu Z, Beilman D, Camill P, Alm J, Amesbury MJ, Anderson D, Andersson S, Bochicchio C, Barber K, Belyea LR, Bunbury J, Chambers FM, Charman DJ, De Vleeschouwer F, Fiałkiewicz-Kozieł B, Finkelstein SA, Gałka M, Garneau M, Hammarlund D, Hinchcliffe W, Holmquist J, Hughes P, Jones MC, Klein ES, Kokfelt U, Korhola A, Kuhry P, Lamarre A, Lamentowicz M, Large D, Lavoie M, MacDonald G, Magnan G, Mäkilä M, Mallon G, Mathijssen P, Mauquoy D, McCarroll J, Moore TR, Nichols J, O'Reilly B, Oksanen P, Packalen M, Peteet D, Richard $\mathrm{PJH}$, Robinson S, Ronkainen T, Rundgren M, Sannel ABK, Tarnocai C, Thom T, Tuittila E-S, Turetsky M, Väliranta M, van der Linden M, van Geel B, van Bellen S, Vitt D, Zhao Y, Zhou W (2014) A database and synthesis of northern peatland soil properties and Holocene carbon and nitrogen accumulation. Holocene 24(9):1028-1042

Longton RE (1988) Biology of polar bryophytes and lichens. Cambridge University Press, Cambridge

Malmer N, Horton DG, Vitt DH (1992) Element concentrations in mosses and surface waters of western Canadian mires relative to precipitation chemistry and hydrology. Ecography 15 : 114-128

Malmer N, Albinsson C, Svensson BH, Wallén B (2003) Interferences between Sphagnum and vascular plants: effects on plant community structure and peat formation. Oikos 100: 469-482

McKnight TL, Darrel H (2000) Climate Zones and Types: The Köppen System. In: Hess D, Tasa DG (eds) Physical Geography: A Landscape Appreciation. Prentice Hall, Upper Saddle River, pp 235-237

Melillo JM, Aber JD, Muratore JF (1982) Nitrogen and lignin control of hardwood leaf litter decomposition dynamics. Ecology 63:621-626

Minderman G (1968) Addition, decomposition and accumulation of organic matter in forests. J Ecol 56:355-362

Mullen SF, Janssens JA, Gorham E (2000) Acidity of and the concentrations of major and minor metals in the surface waters of bryophyte assemblages from 20 North American bogs and fens. Can J Bot 78:718-727

Nordén B, Bohlin E, Nilsson M, Albano A, Rockner C (1992) Characterization of particle size fractions of peat, an integrated biological, chemical, and spectroscopic approach. Soil Sci 153:382-396

Olefeldt D, Turetsky MR, Crill PM, McGuire AD (2013) Environmental and physical controls on northern terrestrial methane emissions across permafrost zones. GCB 19:589603

Ralph J, Hatfield RD (1991) Pyrolysis-GC-MS Characterization of Forage Materials. J Agric Food Chem 39:1426-1437

Rasmussen S, Wolff C, Rudolph H (1995) Compartmentalization of phenolic constituents in Sphagnum. Phytochemistry 38: 35-39

Renberg I, Segerström U (1981) The initial points of the shoreline displacement curve for Southern Västerbotten, dated by varve-counts of Lake sediments. Striae 14:174-176 
Rudolph H, Samland J (1985) Occurrence and metabolism of sphagnum acid in the cell walls of bryophytes. Phytochemistry 24:745-749

Shaw J (2000) Phylogeny of the Sphagnopsida based on chloroplast and nuclear DNA sequences. Bryologist 103:277-306

Spearing AM (1972) Cation-exchange capacity and galacturonic acid content of several species of Sphagnum in Sandy Ridge bog, Central New York State. Bryologist 75:154-158

Straková P, Anttila J, Spetz P, Kitunen V, Tapanila T, Laiho R (2010) Litter quality and its response to water level drawdown in boreal peatlands at plant species and community level. Plant Soil 335: 501-520

Straková P, Penttilä T, Laine J, Laiho R (2012) Disentangling direct and indirect effects of water table drawdown on above- and belowground plant litter decomposition: consequences for accumulation of organic matter in boreal peatlands. Glob Chang Biol 18(1):322-335. doi:10.1111 j.1365-2486.2011.02503.x

Theander O, Westerlund EA (1986) Studies on dietary fiber 3. Improved procedures for analysis of dietary fiber. J Agric Food Chem 34:330-336

Tsuneda A, Thormann MN, Currah RS (2001) Modes of cell-wall degradation of Sphagnum fuscum by Acremonium cf. curvulum and Oidiodendron maius. Can J Bot 79:93-100

Turetsky MR (2003) The role of bryophytes in carbon and nitrogen cycling. Bryol 106:395-409

Turetsky MR, Crow SE, Evans RJ, Vitt DH, Wieder RK (2008) Trade-offs in resource allocation among moss species control decomposition in boreal peatlands. J Ecol 96:1297-1305

Turetsky MR, Bond-Lamberty B, Euskirchen E, Talbot J, Frolking S, McGuire AD, Tuiitla E-S (2012) The resilience and functional role of moss in boreal and arctic ecosystems. New Phyt 196:49-67
Tydén-Ericsson I (1973) A new pyrolyzer with improved control of pyrolysis conditions. Chromatographia 6:353-358

Van Breemen N (1995) How Sphagnum bogs down other plants. TREE 10:270-275

Van der Heijden E, Jauhiainen J, Silvola J, Vasander H, Kuiper PJ (2000) Effects of elevated atmospheric $\mathrm{CO}_{2}$ concentration and increased nitrogen deposition on growth and chemical composition of ombrotrophic Sphagnum balticum and oligomesotrophic Sphagnum papillosum. J Bryol 22:175-182

Van Smeerdijk DG, Boon JJ (1987) Characterization of subfossil Sphagnum leaves, rootlets of Ericaceae and their peat by pyrolysis - high resolution gas chromatography - mass spectrometry. J Anal Appl Pyrolysis 11:377-402

Verhoeven JTA, Liefveld WM (1997) The ecological significance of organochemical compounds in Sphagnum. Act Bot Neerl 46:117-130

Vitt DH, Slack NG (1984) Niche diversification of Sphagnum relative to enviromental factors in northern Minnesota peatlands. Can J Bot 62:1409-1430

Vitt DH, Horton DG, Slack NG, Malmer N (1990) Sphagnumdominated peatlands of hyperoceanic British Columbia coast: patterns in surface water chemistry and vegetation. Can J For Res 20:669-711

Wardle DA, Bardgett RD, Klironomos JN, Setälä H, Van der Putten WH, Wall DH (2004) Ecological linkages between aboveground and belowground biota. Science 304:16291633

Wheeler BD, Proctor MCF (2000) Ecological gradients, subdivisions and terminology of north-west European mires. J Ecol 88:187-203

Williams CJ, Yavitt JB, Wieder RK, Cleavitt NL (1998) Cupric oxide oxidation products of northern peat and peat formingplants. Can J Bot 76:51-62 